\title{
Observations on trade in laughingthrushes (Garrulax spp.) in North Sumatra, Indonesia
}

\author{
CHRIS R. SHEPHERD
}

\section{Summary}

The trade in laughingthrush species native to Indonesia is not carried out in accordance with Indonesian legislation and regulations. During 65 surveys carried out in bird markets in 19972008 , more than 11 , Ooo laughingthrushes representing 10 species were observed, including all five species native to Indonesia. Bird dealers claim that these species are becoming increasingly scarce in Indonesia due to over-harvesting for trade, especially the Sumatran endemic Black-andwhite Laughingthrush G. bicolor and the Javan endemic Rufous-fronted Laughingthrush G. rufifrons. Indonesia has legislation in place to protect these species from over-exploitation, yet the illegal trade continues on a large scale, carried out openly in city bird markets. Enforcement of this legislation is critical in order to prevent these species from becoming perilously threatened.

\section{Introduction}

Laughingthrushes (genus Garrulax) of the family Timaliidae are native to Asia, with the majority found in the Himalayan region and southern China. Five species are native to Indonesia, being confined to the Greater Sundas, including Kalimantan (Indonesian Borneo), Sumatra and Java. Popular as cage birds, both native and non-native species are commonly available in bird markets in Indonesia (Shepherd et al. 2004, Shepherd, 2006, Shepherd 2007). All are wild-caught; there is no commercial breeding of these species in Indonesia.

Of the five laughingthrush species native to Indonesia, the Rufous-fronted Laughingthrush G. rufifrons is endemic to the island of Java and Black-and-white Laughingthrush G. bicolor is endemic to the island of Sumatra (Collar 2006). These island species are of special concern, as single-island endemics are usually at greater risk of extinction than more widespread species (Brooks et al. 1997; van Balen 1999): the Rufous-fronted Laughingthrush is 'Near Threatened', the Black-and-white Laughingthrush 'Vulnerable'. Trade, combined with habitat loss, is suspected to be a threat to the conservation of these island-endemic and other laughingthrush species. Trapping for commercial trade has already greatly reduced populations of the Black-and-white Laughingthrush in the wild (Shepherd 2007, BirdLife 2009, Brickle 2009). Higher elevation habitats, where most laughingthrush species occur, have for a long time been left intact and are not heavily logged in Sumatra compared to lowland forests. However, as lowland forests disappear, these once safe havens are increasingly threatened by the saw and axe, and thus higher elevation species may also be in grave danger due to habitat loss and increased access for bird trappers.

This paper considers the trade in laughingthrushes in North Sumatra, where the most significant bird trade in Sumatra occurs, and looks at relevant legislation and regulations.

\section{Legislation}

Within Indonesia, the Rufous-fronted Laughingthrush is protected under Undang-undang Republik Indonesia No. 5 Tahun 1990 tentang Konservasi Sumber Daya Alam Hayati dan 
Ekosistemnya (Act of the Republic of Indonesia No. 5 of 1990 concerning Conservation of Living Resources and their Ecosystems) widely known as UU No 5 or Act No 5, which means no harvest or trade of this species is permitted. Although the other laughingthrush species are not protected under this act, trade can only occur if there is a quota.

Quotas are set annually by the Scientific and Management Authorities, in consultation with conservation NGOs, researchers and wildlife traders. At the 2008 annual quota-setting meeting in Indonesia, a proposed harvest and trade quota for the White-crested Laughingthrush was discussed. However the proposal was rejected because it referred to the species by its former name G. leucolophus, thus including non-endemic forms, and not as the newly separated endemic G. bicolor (Collar 2006).

Furthermore all traders must be registered with the Directorate General of Forest Protection and Nature Conservation (PHKA - the CITES Management Authority). Anyone not registered is not permitted to harvest or trade. Also, the Decree of the Ministry of Forestry No. 447/Kpts-1I/ 2003 (revised from Decree of the Ministry of Forestry No. 62/Ktps-II/I998) requires any harvest or capture and distribution of wild plant and animal specimens to be done under a licence. Sending or transporting wildlife from one location to another within Indonesia must be covered by legal documents, according to Article 42, Chapter X of the Regulations of the Government of the Republic of Indonesia Number 8 (1999), whether the species is protected by law or not. Collectors (trappers) and suppliers (dealers) must be registered with regional offices for the Natural Resources Conservation Agency (BKSDA), the agency under PHKA responsible for the regulation of harvest and trade in wildlife at the provincial level.

Of all the laughingthrushes, only one, the widespread Chinese Hwamei Garrulax canorus, is listed in the Appendices of the Convention on International Trade in Endangered Species of Wild Fauna and Flora (CITES). The species is listed in CITES Appendix II, which means regulated international trade is permitted, provided it is done in accordance with national legislation. No Indonesian laughingthrush species are currently listed in the Appendices of CITES. Indonesia has been Party to CITES since 1978, the convention entering into force in Indonesia in March 1979.

Finally, international trade in birds with Indonesia has been forbidden since 2005 due to the risk of avian influenza (this ban remains in place for wild-caught birds from Indonesia at the time of writing this paper) under the National Strategic Plan for Avian Influenza Control in Indonesia, Ministry of Agriculture.

\section{Methods}

The largest bird markets in Sumatra are found in the city of Medan, North Sumatra. A total of 65 surveys were carried out in each of the three bird markets of Medan, monthly from 1997 to 2001, inclusive, and on an ad hoc basis until 2008. The last surveys were carried out in July 2008. During each survey, carried out by the author, the number and identity of all species were recorded. These methods provide an indication of availability, not absolute turnover. While turnover cannot be measured using these methods, it is suspected that birds were not likely to be counted twice, as dealers claimed these birds did not remain in stock for more than a month. Unstructured interviews were carried out with all 12 dealers in the bird markets during the July 2008 survey, with questions asked regarding trends, prices and sources. All dealers questioned had long-time experience in the bird trade. Information regarding the effects of the avian influenza scare on the market was also recorded.

Further information was collected from published and unpublished reports on the trade in birds in Indonesia. Information on the CITES-reported trade in Chinese Hwamei was also obtained from the UNEP-WCMC CITES trade database (http://www.unep-wcmc.org/citestrade/ - downloaded 31 July 2008).

Prices were recorded for all species observed in July 2008, and are reported here in US Dollars (USD), although prices were collected in Indonesian Rupiah ( 1 USD $=10,000$ Indonesian Rupiah [IDR]). No birds were purchased during this study. 


\section{Observations}

During 65 surveys carried out in each of the three markets of Medan, North Sumatra, a total of 11,007 laughingthrushes were observed. Ten different laughingthrush species were offered for sale, including all five species native to Indonesia (Table 1 ). Despite legislation and regulations effectively prohibiting trapping and trade, dealers displayed the birds openly, indicating that enforcement of these regulations is lacking. When dealers were asked about the legality of the trade, they acknowledged that trade in the imported Chinese Hwamei was illegal and in violation of international regulations but were not aware of bans on trade in native species. Dealers also stated that permits were not used to move birds from source areas to markets, although most admitted that permits were actually required for this. Dealers stated (during 2007-2008 surveys) that there should be no trade, domestic or international, in any birds at this time due to restrictions put in place to combat the risk of avian influenza. The number of shops in the main market in Medan dropped from 32 in the late 1990 so 12 in 2008, reportedly as a result of the impact of avian influenza-related restrictions on bird trade.

The White-crested Laughingthrush was the most numerous species in trade, with a total of 3,422 specimens observed in market surveys. However, most were observed before the Black-andwhite Laughingthrush was distinguished as a species. In the three surveys carried out after the species were split, only three White-crested Laughingthrushes were observed for sale. The dramatic decline is not only due to Black-and-white Laughingthrush specimens being counted separately, but also due to avian influenza restrictions on importing birds from mainland Southeast Asia. In the same three surveys, 94 Black-and-white Laughingthrushes were observed in the same market.

Only four species of laughingthrush were observed to be traded in numbers significant enough to measure trends (using coefficient of determination): G. chinensis, G. leucolophus (combined with G. bicolor), G. mitratus and G. palliatus. Numbers of all four of these species combined declined significantly during the period of this study (Figure 1 ).

During the most recent survey (July 2008), the Black-and-white Laughingthrush was the most numerous of the laughingthrush species observed for sale (Table 2). However, only two of the 12 shops in the largest market carried them, one with 31 birds, the second with only two. None were observed in the other two markets. The dealer with 31 birds stated that he had bought them from other shops in the same market, as well as from local people who brought them in for sale. He said that it was currently the season for capturing this species, but was not sure where they came from. The second dealer stated that this species was increasingly difficult to obtain, and that currently they were being captured in the Kabanjahe area (in the province of Aceh). She went on

Table 1. Laughingthrush species observed for sale in three markets in Medan, North Sumatra, 1997-2008.

\begin{tabular}{|c|c|c|c|c|c|c|c|c|c|}
\hline Species & $\begin{array}{l}1997 \\
(12)\end{array}$ & $\begin{array}{l}1998 \\
(12)\end{array}$ & $\begin{array}{l}1999 \\
(12)\end{array}$ & $\begin{array}{l}2000 \\
(12)\end{array}$ & $\begin{array}{l}2001 \\
(12)\end{array}$ & $\begin{array}{l}2005 \\
(2)\end{array}$ & $\begin{array}{l}2007 \\
(1)\end{array}$ & $\begin{array}{l}2008 \\
(2)\end{array}$ & Total \\
\hline Garrulax canorus & 2 & $\mathrm{o}$ & 234 & 255 & 131 & 13 & 1 & 7 & 643 \\
\hline Garrulax chinensis & 800 & 924 & 226 & 350 & 207 & 2 & o & 16 & 2,525 \\
\hline Garrulax erythrocephalus & o & 4 & o & o & o & o & o & o & 4 \\
\hline Garrulax formosus & o & o & 1 & $\mathrm{o}$ & o & 1 & o & o & 2 \\
\hline Garrulax leucolophus & 850 & 815 & 645 & 532 & 550 & 27 & 13 & 84 & 3,422 \\
\hline Garrulax lugubris & 6 & 58 & 2 & 18 & 13 & 4 & $\mathrm{o}$ & o & 101 \\
\hline Garrulax mitratus & 550 & 524 & 310 & 252 & 147 & 52 & 8 & o & 1,843 \\
\hline Garrulax palliatus & 400 & 425 & 884 & 364 & 260 & 18 & 6 & 2 & 2,359 \\
\hline Garrulax rufifrons & o & $\mathrm{o}$ & 1 & 9 & 2 & 1 & o & 1 & 14 \\
\hline Garrulax bicolor & $*$ & * & * & $*$ & $*$ & $*_{\mathrm{O}}$ & 12 & 82 & 94 \\
\hline
\end{tabular}

${ }^{*}$ G. bicolor and G. leucolophus were combined for all but three surveys

(\#) denotes the number of surveys carried out each year 


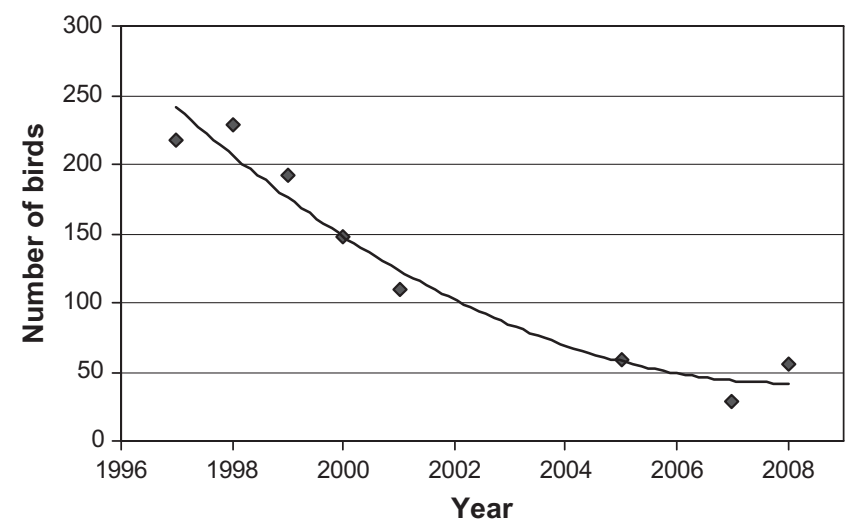

Figure 1. Trend in availability of four significantly traded laughingthrush species in Medan, North Sumatra, 1997-2008.

to say that they only receive one or two for sale at a time. Dealers in all 12 shops stated that it was becoming increasingly difficult for trappers to obtain these birds, and therefore they were scarcer in the markets than they had been in the past. One dealer stated that the selling price for this species was too low and was therefore not worth searching for.

Of all the laughingthrush species observed during this study, only the imported Chinese Hwamei is listed by CITES, in Appendix II. CITES annual data do not show any reported trade in Chinese Hwamei to Indonesia. Dealers claim that this species is smuggled into the country, often in shipments of other bird species. Dealers also state that there is no captive breeding of this or any other laughingthrush species in Indonesia and that all native species are sourced from the wild. It is unknown whether the Chinese Hwamei brought into Indonesia originated from the wild or were captive-bred.

Table 2. Status and price of laughingthrush species observed for sale in Medan, North Sumatra, 1997-2008.

\begin{tabular}{|c|c|c|c|c|}
\hline Species & $\begin{array}{l}\text { IUCN } \\
\text { status* }\end{array}$ & $\begin{array}{l}\text { Native to } \\
\text { Indonesia }\end{array}$ & $\begin{array}{l}\text { Price } \\
\text { USD } \\
(2008)\end{array}$ & $\begin{array}{l}\text { Total number } \\
\text { observed } \\
\text { (65 surveys) }\end{array}$ \\
\hline Sunda Laughingthrush Garrulax palliatus & $\mathrm{LC}$ & Yes & 10 & 2,359 \\
\hline Rufous-fronted Laughingthrush Garrulax rufifrons & NT & Yes $^{* *}$ & 45 & 14 \\
\hline Black-and-white Laughingthrush Garrulax bicolor ${ }^{* * *}$ & VU & Yes $^{* *}$ & $10-35$ & 94 \\
\hline Black Laughingthrush Garrulax lugubris & LC & Yes & 15 & 101 \\
\hline Chestnut-capped Laughingthrush Garrulax mitratus & LC & Yes & 10 & 1,843 \\
\hline Chinese Hwamei Garrulax canorus & $\mathrm{LC}$ & No & 30 & 643 \\
\hline Black-throated Laughingthrush Garrulax chinensis & $\mathrm{LC}$ & No & $50-100$ & 2,525 \\
\hline White-crested Laughingthrush Garrulax leucolophus*** & $\mathrm{LC}$ & No & 15 & 3,422 \\
\hline Chestnut-crowned Laughingthrush Garrulax erythrocephalus & LC & No & $\mathrm{n} / \mathrm{a}$ & 4 \\
\hline Red-winged Laughingthrush Garrulax formosus & $\mathrm{LC}$ & No & $\mathrm{n} / \mathrm{a}$ & 2 \\
\hline Total & & & & 11,007 \\
\hline
\end{tabular}

${ }^{*}$ IUCN 2008. 2008 IUCN Red List of Threatened Species. <www.iucnredlist.org>. Downloaded on 7 December 2008.

${ }^{* *}$ endemic to Indonesia

${ }^{* * *}$ G. bicolor and G. leucolophus were combined for all but three surveys 


\section{Prices}

There does not appear to be any significant correlation between the price and the scarcity or abundance of the species. Instead price depends largely on singing ability (although dealers sometimes use rarity as a reason to increase prices). Some species, such as the Black-throated Laughingthrush G. chinensis and the Chinese Hwamei, are regarded as good singers and are even included in local bird singing competitions. They therefore command higher prices than species considered to be inferior singers.

The most expensive laughingthrush species observed in the markets was the Black-throated Laughingthrush with some individuals costing as much as USD 10o.oo (Table 2). Dealers claimed that exceptional singers of this species could cost as much as ten times this price, but no bird costing that much were observed during these surveys. Less expensive birds, such as the Chestnut-capped Laughingthrush, costing approximately USD 10.00, are considered birds for the layman and not the serious songbird hobbyist.

Prices for the two Indonesian endemic species were not particularly high, as neither is highly prized as a songster. However the Rufous-fronted Laughingthrush, which according to dealers is much more difficult to acquire in Medan, demanded a higher price than the Black-and-white Laughingthrush. Prices for the Black-and-white Laughingthrush rose from USD 8.00 to 15.00 in 2007, to USD 10.00-30.00 in 2008, although dealers did not give a reason for this.

\section{Discussion}

The trade in laughingthrush species native to Indonesia is not carried out in accordance with Indonesian legislation and regulations. The species observed in trade are captured, transported and sold illegally, in violation of a number of harvest and trade regulations. The majority of bird traders operating in North Sumatra are doing so without a licence to buy and sell birds.

The trade in non-native laughingthrush species is also largely carried out in contravention of Indonesia's regulations, as the vast majority of these birds, if not all, have been moved to markets in Indonesia without the required permits to do so. The trade in the Chinese Hwamei, the only CITES-listed laughingthrush species observed during this study, may also be carried out in contravention of CITES, as none have been reported in trade to Indonesia since the species was first listed in Appendix II in 2000.

The trade in laughingthrushes may be causing declines in the wild. According to bird dealers in the bird markets in Medan, a number of laughingthrush species, such as Black-and-white Laughingthrush and Rufous-fronted Laughingthrush, are becoming increasingly rare or difficult to find in economically viable numbers. Recent searches for the Black-and-white Laughingthrush in the wild have concluded that the species is now very hard to see in the wild because they have been trapped out of all readily accessible areas (Brickle, 2009).

\section{Recommendations}

Research into the conservation status of these species in Indonesia and the impacts of illegal trade and other threats, such as habitat loss, is imperative. The authorities should be encouraged to promote the conservation of these species at a national level and to take strict enforcement action against traders violating laws and regulations relevant to the bird trade. Consumers (the public) should be educated about legislation currently banning trade in these species and furthermore made aware of the need for their conservation.

\section{Acknowledgements}

Thanks are due to Andrew Owen, Ian Hadgkiss and Ian Edmans, The Aviary, Waddesdon Manor, UK for supporting work on Garrulax bicolor in Indonesia. Thanks are also due to Richard 
Thomas and Teresa Mulliken for very helpful comments on an earlier draft of this paper. Vincent Nijman is also thanked for very useful comments and discussion regarding the analysis and findings of this study.

\section{References}

BirdLife International (2009) Species factsheet: Garrulax bicolor. Downloaded from http://www.birdlife.org on 14/11/2009.

Brickle, N. (2009) Seeking the elusive Blackand-white Laughingthrush Garrulax bicolor in the Alas Valley. Birding ASIA 11: 15.

Brooks, T. M., Pimm, S. L. and Collar, N. J. (1997) Deforestation predicts the number of threatened birds in insular Southeast Asia. Conserv. Biol. 11: 382-394.

Collar, N. J. (2006) A partial revision of the Asian babblers (Timaliidae). Forktail 22: 85-112.

Shepherd, C. R. (2006) The bird trade in Medan, north Sumatra: an overview. Birding ASIA 5: 16-24.

Shepherd, C. R. (2007) Trade in the Blackand-white Laughingthrush Garrulax bicolor and White-crested Laughingthrush G. leucolophus in Indonesia. Birding ASIA 8: 49-52.

Shepherd, C. R., Sukumaran, J. and Wich, S. A. (2004) Open season: An analysis of the pet trade in Medan, Sumatra 1997-2001. Selangor, Malaysia: TRAFFIC Southeast Asia.

van Balen, S. (1999) Birds on fragmented islands: persistence in the forests of Java and Bali. Wageningen, The Netherlands: Wageningen Agricultural University. (Tropical Resource Management Papers 30).

\section{CHRIS R. SHEPHERD*}

TRAFFIC Southeast Asia, Unit 3-2, $1^{\text {st }}$ floor, Jl SS $23 / 11$, Taman SEA, Petaling Jaya, Selangor, Malaysia and Oxford Brookes University, School of Social Sciences and Law, Gipsy Lane, $\mathrm{OX}_{3}$ oBP, Oxford, U.K.

*Author for correspondence e-mail: cstsea@po.jaring.my

Received 19 February 2009; revision accepted 12 March 2010;

Published online 26 April 2010 